\title{
The Impact of Dividend Policy on the Shareholders Value of Listed Firms in the Nigerian Petroleum Marketing Industry
}

\author{
Alhaji Ali Tijjani, Mohd Norfian Alifiah and Gana Kafiya Wakil
}

\begin{abstract}
Dividend policy is directed towards establishing the proportion of current income that should be retained in the firm and the proportion that should be distributed among its shareholders. This study, therefore, assessed the impact of dividend policy on the value of listed firms in the Nigerian petroleum marketing industry. six firms, out of eight that are quoted on the Nigerian Stock Exchange (NSE) were selected as sample for the study. Data were collected from secondary sources. Annual reports and accounts of the selected firms, daily official lists and facts books of the NSE for the period of 2008-2017 form the source of the data. egression was used in analyzing the data. The findings revealed that payment of dividend by petroleum marketing firms in Nigeria positively influence the market price of their shares. Based on these findings, the study concluded that dividend policy of petroleum marketing firms in Nigeria affects the value of the firms. Based on this conclusion, the study recommends that management need to identify the shareholder's interest in setting up a dividend policy that would balance their needs and retention for recapitalization to maximize value of the firms.
\end{abstract}

Index Terms: Dividend, Dividend policy, Investment, Market price, Shareholders value.

\section{INTRODUCTION}

Dividend is the share of company's net profit made available to shareholders as return on their investment in a company. It can be paid to shareholders either in cash (where cash is paid out) or stock (where the profit is ploughed back, and bonus share is issued to the shareholders in its place) or it can be paid both in cash and in stock. It is a point of interest to investors to hear that at the end of every financial year, net earnings remaining after other appropriations, namely payment of company income tax, transfer to reserve accounts and retained earnings is paid out as dividend. Payment of dividend has the tendency to enhance the firms' share value in the capital market as a result of its informational content about the performance of the firm. On the other hand, retained profits can also be reinvested in the company with a view to taking advantages of economies of scale and economies of scope which would result in greater performance of the firm that can also enhance the market value of the firm in the long run. An effective dividend policy

Revised Manuscript Received on September 22, 2019.

Alhaji Ali Tijjani, Accounting and Finance, Universiti Teknologi Malaysia. Email: aatij55@yahoo.com

Mohd Norfian Alifiah, Accounting and Finance, Universiti Teknologi Malaysia.

Gana Ksfiya Wakil, Accounting and Finance, Universiti Teknologi, Malaysia. is, therefore, extremely important to a company in its desire to maximize the wealth of its shareholders. Similarly, adequate knowledge of dividend policy of companies would guide investors in their choice of investments.

Dividend policy is directed towards establishing the proportion of current income that should be retained in the firm and the proportion that should be distributed among its shareholders. Dividend policy has greatly caught the attention of financial analysts the world over in the last five decades. It also has been a source of controversy and a subject of intensive theoretical and empirical examination. The linkage between dividend policy and share prices remains one aspect of dividend policy that is puzzling. The amount that shareholders are willing to pay in exchange for shares of a company can be influenced by the firm's dividend policy (Van Horne, 1998; Pandey, 2005).

Once management pursues a dividend policy that is contrary to the shareholders interest, dissatisfied investors will sell their holdings. Widespread selling will increase the supply of the firm's share in the market and can result in low prices, subsequently affecting the value of the firm. If a firm retains profit rather than declaring dividends, the price of the firm's shares can rise accordingly. However, shareholders desiring a current return always create "homemade" dividends by selling some shares and capture the appreciated value Furthermore, if all the profits of the firm are distributed immediately to the shareholders, the value of the firm might be affected. Those shareholders, who invest for capital growth and future income, expecting the firm to grow by ploughing back its profits, might begin to sell their shares (Stulz, 2000). The impact of dividend policy on the value of firm has been upheld as evidenced by the findings of Mainoma (2001), Nishat and Irfan (2003). The dividend policy of a firm is directed towards establishing the proportion of current income that should be retained and the proportion that should be distributed among its shareholders. This has been an issue of contrivance and a subject of intensive theoretical and empirical examination. The linkage between dividend policy and share prices remains one aspect of dividend policy that is puzzling. However, the amount that shareholders are willing to pay in exchange for shares of a company is influenced by the firm's dividend policy (Van Horne, 1998; Pandey, 2005).

The main objective of a firm is to maximize shareholder's wealth which is represented by value creation on the market price of a company's share. Value creation can be achieved by retaining some earnings for reinvestment and 
dividend growth in the future Pandey (2005). Most firms strive for the satisfaction of shareholder's need for current income through dividend payout. The firms believe that paying dividends reduces risk and thus influences share prices as an indicator for future earnings. However, dividend payout reduces the amount available for internal financing. Therefore, what get to the shareholders in the short run constitute an important decision for the overall survival of the firm.

Dividend policy connotes to the payment policy, which managers pursue in deciding the size and pattern of cash distribution to shareholders over time. Managements' primary goal is shareholders' wealth maximization, which translates into maximizing the value of the company as measured by the price of the company's common stock. This goal can be achieved by giving the shareholders a "fair" payment on their investments, (Olang, Akenga, \& Mwangi, 2015).

Dividends tend to be paid by mature, established firms, plausibly reflecting a financial life cycle in which young firms face relatively abundant investment opportunities with limited resources so that retention dominates distribution, whereas mature firms are better candidates to pay dividends because they have higher profitability and fewer attractive investment opportunities (Deangelo \& Deangelo, 2006).

Dividend policy is company's guiding documents on dividend measurement and payment. Meanwhile, dividend policy is not the only measure of firms' performance, in which there are other means as evidenced by Jabbouri (2016). According to Khan (2015), dividend policy of a company can be measured using two common appropriate methods, dividend yield and dividend payout ratio. Changes in these two financial measures provide information signals in relation to risks facing the firms and future growth earnings of the firms. Apart from dividend policy indicators, investors also see other financial indicators to make decisions pertaining to the firms efficiency such as earnings per share, retained earnings, firm size and book value (Chelimo \& Kiprop, 2017).

Dividend payout might be high or low. A low payout means more retained earnings and might produce a higher share prices because it accelerates earnings growth. Investors of growth companies will realize their returns mostly in forms of future capital gains. The impact of dividend policy on future capital gains is however complex and uncertain because it occurs in the distant future. Therefore, low payout may not necessarily lead to higher prices. On the other hand, high payout means more current dividend and less retained earnings, which may consequently result in slow growth and perhaps lower market share price. Nevertheless, some of the shareholders especially the minority ones, their major objective is to have dividend at the end of the period, while others concern with growth to have future capital gains.

Investors differ significantly in their investment decisions. Some investors are interested in immediate returns while others are interested in the growth of capital and future income. Whatever dividend policy a firm adopts may affect it positively or negatively depending on its investor's attitude. It is quite rational that some investors would prefer high-payout companies while others may prefer low-payout companies. Therefore, management has to strike a balance between opposing interests of the firm and the shareholders. Hence, determination of optimal dividend payout ratio is extremely important for the survival of the firm. That is why now there are a lot of arguments on the issue of capital gain and outright payments of dividend, (Ahmed \& Murtaza, 2015). Dividend policy (DP) is considered as one of the three major decisions of financial management. The decision of the firm regarding how much earnings could be paid out as dividend and how much could be retained by the firm is the concern of DP. The DP determines what proportion of earnings is paid out to shareholders by way of dividends and what proportion is ploughed back in the firm itself for reinvestment purposes. The development of such a policy will be greatly influenced by investment opportunities available to the firm and the value of dividends as against capital gains to the shareholders. Each firm should develop such a DP, which divides the net earnings into dividends and retained earnings in an optimum way to achieve the objective of maximizing the wealth of the shareholders (Pandey \& Ashvini, 2016).

However, despite the number of studies that have been done on dividend policy, it remains an unresolved issue in corporate finance. Several theories have been proposed to explain the relevance of dividend policy and whether it affects firm value, but there has not been a universally agreed stand. As a result, researchers continue to come up with divergent findings on the relationship between dividend payout and firm value.

However, none of these studies was specifically on the Nigerian petroleum marketing industry. This study therefore differs from the previous studies in several respects. Firstly, it focuses entirely on the Nigerian petroleum marketing company and utilizes a model that has been developed by Musa (2005) which captures some factors that are considered sensitive and relevant to the Nigerian economy, and the model has been tested and validated by a number of previous studies (Musa, 2005). Secondly, the period covered by this research (2006 to 2015) is unique to this study and substantially encompasses the dynamism of the Nigerian operating environment. Thirdly, the study is current and topical because of the need for greater investment in the sector with a view to improving the supply, distribution and marketing of petroleum products in the country to avert the scarcity of petroleum product experienced in the country from time to time. Finally, most recent studies on dividend policy in Nigeria focus attention on investing the dividend policy rather than its impact on firm's value. Therefore, it is against this backdrop that this study is carried out with the aim of determining the impact of dividend policy on the value of firms in the Nigeria petroleum marketing industry. As an industry-specific effort, the study is expected to not only extend the frontiers of knowledge in accounting and finance, but also provide a framework upon which the dividend policy of Nigeria petroleum marketing industry would be modeled. The aim of this study is to examine the impact of dividend policy on value of listed firms in the Nigeria petroleum marketing industry. The specific objective of the study is to assess the impact of dividend payout on market value of firms in the Nigerian petroleum marketing industry.

Based on the objective of the study, the following research question is raised to guide the study in the collection and interpretation of data. Does dividend payout have a significant impact on market value of firms in the Nigerian petroleum marketing industry? Based on the objective the following hypotheses were formulated. 
Ho: dividend payout of petroleum marketing firms in Nigeria has no significant impact on the value of shares

There are several benefits that are expected to be derived from this research, thus signifying that the study is significant. Firstly, given the controversies and inconclusiveness of the findings of several studies on dividend policy both in Nigeria and beyond, this study would help in carrying the debate forward thereby extending the frontiers of knowledge. The study therefore hopes not only to help enrich the literature, but also provides important quantitative information that would be important to managers and shareholders of firms in the Nigeria petroleum marketing industry.

Similarly, dividend policy has no doubt influences the decision of both local and foreign investors. Studies on dividend policy are therefore of clear policy relevance, especially for a country that is desirous of rapid and sustained economic growth by attracting foreign direct investment into the country. Moreover, the study examines how dividend policy influences firm value of listed petroleum marketing firms in Nigeria. This review is very important to researchers in understanding the relationship between dividend policy and firm's value in Nigeria with a view to affirming or negating previous work in the field.

Furthermore, managements of petroleum marketing industry may find this study useful. The findings of the study may enable them to appreciate the impact of dividend policy on the value of their firms. Finally, general public may obtain a better understanding of the various determinants of a firm's dividend policy and how such policy relates to firm's value. The study will focus on the impact of dividend policy on the value of listed firms in the Nigeria petroleum marketing industry. The study focuses on the impact of dividend payout on the market prices of the shares, the study is based on data obtained from secondary sources (daily official list and fact book of NSE) for the period of ten years from 2006 to 2015, and six out of eight petroleum marketing firms listed on the Nigeria Stock Exchange (NSE) as at 31st December 2015 would be selected for the study. Some of the limitations of the study are that it focuses on the issues relating to cash dividend and the study focuses only on the marketing and distribution as segment of the oil and gas industry.

\section{THE CONCEPT OF DIVIDEND POLICY}

\section{A. Review Stage}

Dividend is a periodic payment to shareholders to compensate them for the use of their funds by the firm that is making the payment and that it comes in different forms. Van horne (1996) explains that stock dividend which is a form of dividend should simply be the payment of additional stock to shareholders. This is so because it represents nothing more than a recapitalization by the firm: a stockholder's proportional ownership remains unchanged. Similarly, stock dividend is distributed in the stock of the same kind as that on which the dividend was declared, so it is to conserve cash.

The third important decision of a firm is its dividend policy after it has decided on investing in assets and promulgating the best mix of financing (Van Horne, 1998). Dividend policy centres on the appropriation of earnings between shareholders and the company. It determines the amount of earnings to be distributed to shareholders and the amount to be retained in the firm. Retained earnings are significant internal source of financing the growth of the firm (Pandey, 2005).

Dividend policy is a decision that provides an answer to the question; what proportion of total earnings should be retained in the firm and what proportion should be distributed to shareholders? If the dividends payout is high, retained earnings will be low. The determination of the appropriate dividend payout ratio, which could be referred to as an optimal mix of the conflicting desires of the shareholders, is significant to the survival of the firm.

Dividends are mostly paid in cash. The distribution of earnings uses the available cash of the firm. A firm that intends to pay dividends and need funds to finance its investment opportunities will have to use external sources of financing such as the issue of new shares or debt capital. Rozeff (1982) posits that the effect of dividend policy by concluding that "the distribution of cash dividends causes reduction of internal funds available to finance profitable investment opportunities and subsequently, either constrains growth or require the firm to find other costly source of financing." Therefore, firms may retain their earnings as part of long-term financing decision.

Dividend policy suggests a positive attitude for, it is a deliberate policy to maintain or increase dividend at a certain level with the aim of sustaining the price of the ordinary shares on the stock exchange. This is because capital markets are not perfect, although shareholders are indifferent between dividend and retained earnings due to market imperfections and uncertainty, but they give a higher value to the current year dividend than the future dividend and capital gains. Thus, the payment of dividend has a strong influence on the market price of the shares. Management might maintain a dividend level even at the expense of liquidity or forced into borrowing to do so. With this approach it holds that dividends, on the other hand, are desirable from the shareholders point of view, as increasing their current wealth and consequently dividend level determines share price as well as indicates the prospect of profitability of the firm, (Adefila, Oladipo, \& Adoeti, 2000).

Another school of thought holds that without Modigliani and Miller's restrictive assumptions, their argument collapses. They asserted that since, investors operate in a world of brokerage fees, taxes, and uncertainty, it is better to view the firm in the light of these factors. The leading proponent of the relevance of dividend theory, Gordon (1962) suggests that shareholders do prefer current dividends, that, in fact theme is direct relationship between the dividend policy of a firm and its market value. Gordon argues that investors are generally risk-averters and attach less risk to current as opposed to future dividends or capital gains. This "birds in hand" argument suggest that a firm' dividend policy is relevant since investors prefer some dividend now to reduce their uncertainty. When investors are uncertain about their returns they discount the firm's future earnings at a lower rate therefore placing a higher value on the firm, (Adefila et al., 2000). 


\section{B. Empirical Studies on Dividend Policy}

Over the past decades, dividend policy has gained a considerable amount of attention of the researchers and academicians. It has been one of the most debated issues in corporate finance since the publication of the seminal work of (Miller \& Modigliani, 1961). Miller and Modigliani (1961) argued that in perfect markets, the financial managers are unable to change the firms' value by altering their dividend policy. Furthermore, in the real world, the perfect markets do not exist, value of firms is expected to influence dividend policy. Consequently, researchers proposed different theories about the outcome of dividend policy and the factors that influence dividend policy of the firms.

There are a lot of proposals by researchers on the diverse theories about the factors that determine dividend policy of the firms. Despite the fact that numerous models, explanations and theories exist, the generally applied theories include; Bird in the hand theory reported by Walter (1967) and Gordon (1963). According to this theory, cash dividend is the forecast preference of the investors as compared to a future assurance of capital gains due to risk minimization (Al-Malkawi, Rafferty, \& Pillai, 2010; Michelle et al., 2012). Thus, the dividend that mitigates information asymmetry between shareholders and management by transmitting secret information about the future prospects of the firm is referred to as signaling information on dividends (Aggarwal et al., 2012; Al-ghazali, 2014; Al-Kuwari, 2009; Baker \& Kapoor, 2015; Baker \& Powell, 2012; Bhattacharya, 1979; Miller \& Rock, 1985).

Clientele effects and tax preference theory that clarifies discrepancies in tax rates between capital gains and dividends guide to diverse clienteles (Bishop et al., 2000; Dhaliwal et al., 1999; Edwin \& Martin, 1970; Livoreka et al., 2014; Michelle et al., 2012; Stulz, 2000; Van Horne \& Wachowicz, 2005). Agency theory states that dividends assist to mitigate the agency conflict with ownership separation and control (Easterbrook, 1984; Fama \& Jensen, 1983; Hendra et al., 2016; Jensen, 1986; Jensen \& Meckling, 1976; Lang \& Litzenberger, 1989; Rozeff, 1982).

According to life-cycle theory, dividend policy is inclined to pursue a firm's life-cycle and reproduces management's evaluation of the significance of market deficiency, including agency cost, asymmetric information, transaction costs, floatation cost and taxes on equity (Al-Malkawi et al., 2010; Baker \& Kapoor, 2015; Baker, Kilincarslan, \& Arsal, 2018; Baker \& Powell, 2012; Bulan \& Narayanan, 2009; Fairchild et al., 2014; Fama \& French, 2001). Finally, catering theory states that managers present investors what they presently desire, that is, they cater to an investor stipulation by distributing dividends when investors locate a stock price premium on payers, and by not distributing when investors favour non-payers (Baker \& Imad, 2017; Baker \& Kapoor, 2015; Baker et al., 2018; Baker \& Powell, 2000, 2012; Baker \& Wurgler, 2004; Ferris, Jayaraman, \& Sabherwal, 2009; Kuo et al., 2013).

In the strain of dividend policy, researchers documented several factors that influence the dividend decisions. The literature documented historical dividends, expected earnings, stability of earnings, current earnings, asymmetric information, liquidity constraints, stockholders' wealth, leverage, capital structure, growth opportunities, investment plan etc. are the main determinants of dividend policy with respect to different economies and cultures.

There are many studies conducted on the factors that determines the dividend policy which came up with different findings. For instance, the study of dividend policy on the share price by Zakaria et al. (2012) whose studied on price volatility in Malaysia, found that dividend payout significantly influences the changes in share price. This is similar to the findings of Hashemijoo, Ardekani, and Younesi, (2012). Accordingly, Masum (2014), who study in different country and found out that ROE and EPS have a statistically significant positive impact on stock price and PAT has a significant negative impact on stock market prices in Bangladesh. Furthermore, Baker and Powell (2012), found that there is a significant effect between dividend policy and share prices in Indonesian market. Even though the above studies use different variants and in different countries, but the results still remain the same.

Similarly, studies on other determinants of dividend policy give different results; (Celsing, 2017; Kaźmierska-Jóźwiak, 2015; Koussis, Martzoukos, \& Trigeorgis, 2017; Teresiah, 2014; Uwuigbe, Jafaru, \& Ajayi, 2012). These studies found that there exists a relationship between all the firm-level determinants and the dividend policy, but these relationships can either be positive or negative. So, it is against these, that this study wanted to look at the best possible firm level determinants that suite Nigerian environment.

Many researchers from emerging economies supported the results reported from that of developed economies. In this vein, Al-Twaijry (2007) conducted his research on a developing economy of Malaysia and reported an association between dividend payout and current year earnings, expected and past earnings. Furthermore, Al-Malkawi (2007) explored the factors that influence the dividend policy decisions in Jordan. They also reported evidences in line with that reported by Al-Twaijry, (2007) on Malaysian firms listed in Kuala Lampur stock exchange. The results of Al-Twaijry (2007) and Al-Malkawi (2007) were empirically supported by the earliest evidences reported by Baker and Powell, (2000) in their research on listed companies in the NYSE and Baker, Veit, and Powell, (2001) by their research on listed companies in the NASDAQ. Similarly, Tse (2005) explored mix evidences in this line on firms in the UK. Furthermore, a study by Jabbouri (2016), shows that managers of MENA firms seem to increase dividend payouts during economic slumps in an attempt to reassure investors fearing insiders' expropriation. Meanwhile, study by Fairchild, Guney and Thanatawee (2014), examines dividend changes in emerging markets and it considers investor power and ownership on dividends.

Similarly, dividend policy theories have divergent relevance between management and shareholders arising from opposing interests. Accordingly, Oliver et al. (2016), studied on the effect of dividend policy on the value of firms in Nigeria stock exchange. However, the study empirically investigates the effect of dividend policy on the value of firms as reflected on shareholders' wealth maximization. The study revealed that DPS is significantly and inversely related to the value of shares of firms, while EPS is both positive and significant to the value of shares of firms.

Furthermore, studies 
conducted on ownership structure and dividend policy revealed different results. For instance, Gonzalez et al. (2017), studied the effect of ownership concentration and found that where there is high ownership concentration and the largest investor is identified as an individual, firms tend to pay less dividends consistent with individual investors extracting benefits from minority shareholders. However, studies by Bradford, Chen, and Zhu (2013), Firth et al. (2016), He (2012); Mukhtar (2015); Shao, Kwok, and Guedhami (2013), revealed significant relationships between ownership structure and dividend policy of firms. So, it is against these studies that this current research will be conducted to determine the outcome from emerging country like Nigeria.

\section{METHODOLOGY}

This section presents the methodology of the study. It explains the research design, the population of the study, the sample size and sampling technique and the sources and methods of data collection used. It also explains the variables of the study and their measurement and the techniques for statistical analysis of data. The study adopted an ex-post facto research design. Documentary data were obtained from the annual reports and accounts of the firms and the Nigerian Stock Exchange Fact Book. In view of the use of documentary data for the study, the choice of ex-post facto research designs is thought justified. The population of this study comprises all the oil marketing firms quoted on the Nigerian Stock Exchange (NSE) as at 31st December 2017. These companies are eight (8) in number. Availability of data is an important factor of consideration in a study of this nature.

In view of the above discourse, the researcher employed a one-point filter to eliminate the firms that are currently not listed on the NSE and thought unsuitable for the study. The reason for this filtering is not farfetched as may have been seen from the explanations above. The filter is applied to

\begin{tabular}{|c|c|c|c|c|c|c|c|}
\hline $\begin{array}{l}\text { Dependent } \\
\text { variables }\end{array}$ & $\begin{array}{l}\text { Independent } \\
\text { variables }\end{array}$ & $\begin{array}{l}\text { Coefficients } \\
\text { Pooled OLS }\end{array}$ & $\mathrm{p}$-value & $\begin{array}{l}\text { Coefficients } \\
\text { RE }\end{array}$ & p-value & $\begin{array}{l}\text { Coefficients } \\
\text { FE }\end{array}$ & p-value \\
\hline \multirow{7}{*}{$\begin{array}{l}\text { Dividend } \\
\text { Payout }\end{array}$} & $\mathrm{CE}$ & -0.0007 & 0.867 & -0.0007 & 0.867 & -0.0017 & 0.792 \\
\hline & PYD & 0.8129 & 0 & 0.8129 & 0 & 0.2906 & 0.076 \\
\hline & IE & -0.1746 & 0.056 & -0.1746 & 0.05 & -0.1133 & 0.158 \\
\hline & AGE & -4.55 & 0.083 & -4.55 & 0.076 & 5.96 & 0.267 \\
\hline & R-square & 0.525 & & 0.525 & & 0.0692 & \\
\hline & F-Statistics & 13.26 & & 0.0039 & & 0.0029 & \\
\hline & $\begin{array}{c}\text { Prob } \\
\text { (F-statistics }\end{array}$ & 0 & & 0.0284 & & 0.0284 & \\
\hline
\end{tabular}

Table presents the regression result of the dependent variable (DPO) and the variables of the study (current earnings, preceding years' dividend, investment expenditure and age). The OLS regressions do not provide efficient estimates and to check whether the variability of error terms is constant or not, a test for heteroskedasticity was conducted. The heteroskedasticity test performed reveal presence of heteroskedasticity which is corrected using the OLS robust test. In order to examine whether endogeneity exist, which could potentially lead to biased coefficient, a Hausman ensure the availability of comparable data from 2008-2017. Consequently, upon the application of this filter, the population of the study is reduced to six (6) petroleum marketing companies.

In conducting this study, secondary source of data was used. The data were generated from the annual reports and accounts of the selected oil marketing firms, as well as, the Fact Book of the Nigerian Stock Exchange for a period of 10 years from 2008 to 2017 . The techniques of analysis used in this study include Inferential statistics i.e. regression. Hypothesis employed is to determine the impact of dividend policy on the value of firms.

\section{RESULTS AND DISCUSSION}

This section presents, analyses and interprets the data generated for the study. The data relating to each of the variables of the study were presented and analyzed. The data were collected from the annual reports and accounts of the sampled oil marketing companies to determine the impact of the independent variable on the dependent variable. The section starts with the preliminary analysis of the population using inferential statistics then the regression results of the dependent variable (DPO) and the independent variable.

The model comprises of dividend payment of petroleum marketing firms as the dependent variable, while the current earnings, preceding year dividends and age of the firm were the independent variables.

\section{A. Figures and Tables}

The estimated multiple regression model of dividend payment is extracted as follows:

$$
D I V_{i t}=\alpha+\beta_{1} C E_{i t}+\beta_{2} P Y D_{i t}+\beta_{3} I E_{i t}+\beta_{4} A G E_{i t}+\varepsilon_{i t}
$$

specification test to make the choice between fixed effect (FE) and random effect (RE) regression was performed. This test is necessary considering that there is a trade-off between the efficiency of the random effect and the consistency of the fixed approach. The test also determines whether the estimates of the coefficients, taken as a group, are significantly different in the two regressions. If any variables are dropped in the fixed effects regressions, they are excluded from the test. Although, Table presents the regression results

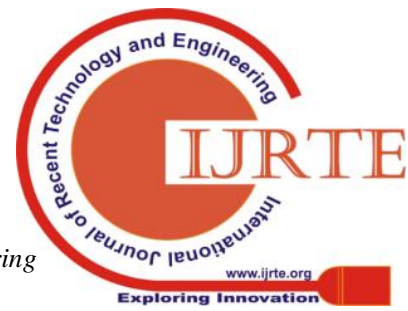


of OLS robust, FE and RE, discussion is done on OLS and RE estimations only. This is due to the fact that the Hausman test reveals that the RE is more efficient as evident by the $p$ value of 0.2345 which is insignificant i.e. greater than 0.05 .

The OLS regression results reveal the cumulative R-square (0.525) which is the multiple coefficient of determination gives the proportion or percentage of the total variation in the dependent variable explained by the explanatory variables jointly. Hence, it signifies $52.5 \%$ of total variation in dividend policy of Nigerian listed oil marketing firms is caused by their current earnings, preceding years' dividend and their investment expenditure. This indicated that the model is fit, and the explanatory variable are properly selected, combined and used as substantial value of the dividend is accounted for by the explanatory variables. This can be confirmed by the value of F-statistics at $5 \%$ level of significance. Hence finding of the study is relied upon.

Therefore, based on these analyses, the null hypothesis is rejected in favour of the alternate hypothesis, because the result shows a positive significant relationship between dividend policy and the market value of firms. The result revealed that the dividend policy of petroleum marketing firms in Nigeria has an impact on the value of their shares during the period of the study.

This evidence reveals the signalling effect of dividend payment to the Nigerian Capital market and confirm the position of Bhattacharya, (1979), Miller \& Rock, (1985), Nishat and Irfan (2003) and Chekole, (2016). This study supports the existing evidence in the literature of dividend relevance propounded by Gordon (1962) and Walter (1963) and reject the stand of Miller and Modigliani (1961) given that their underlying assumptions cannot hold in the Nigeria context, (Sa'adu \& Abdu, 2016).

The result of this study compliments the evidence established in a study carried out on by Arko, Abor, Adjasi, \& Amidu, (2014), a cross-sectional study of Mainoma (2001) and a study undertaken on banking sector by Oyedeko \& Adeneye, (2017) and Musa (2005). The studies revealed significant relationship between dividend policy and the value of firms in Nigeria and provide support to the dividend signalling theory. Companies need to provide attainable combination of dividend per share and stock price appreciation to maximise shareholders' wealth. The study repeals the first null hypothesis that dividend policy of petroleum marketing firms has no impact on their stock prices. The result reveals a significant positive relationship between the dividend payment of petroleum marketing firms in Nigeria and their market values. The appreciation in the market value of the firms can be attributed to dividend payment. The result agrees with the findings of Nishat and Irfan (2003) and supports the dividend-signalling hypothesis (Bhattachayya, 1979).

The implication is that dividend payment made shareholders to firmly hold their investment in the petroleum marketing firms while prospective investors get inspired to own shares of the firms. Therefore, this presence of market forces caused by dividend payment could be responsible for the appreciation of share prices in the capital market. Investors respond to the dividend announcement as an indication of financial prosperity and remove uncertainties in their minds as to the ability of the firms to maximize share values. This confirms the position of Miller and Rock (1985) and Frankfurter and wood (2005).

The study supports the existing evidence in the literature of dividend relevance propounded by Gordon (1962), Walter (1963), Jabbouri, (2016), Tadele, (2017), and rejects the stand of Miller and Modigliani (1961), Denis \& Osobov, (2008) given that their assumptions are not valid in the Nigeria environment. However, this result is not consistent to all firms in the sample. The negative correlation results of MRS (Nigeria) Plc shows that a greater proportion in the appreciation of the firm's market value is due to factors other than dividend. The negative correlation result shows that increase in dividend decreases the market value per share of the firm.

\section{CONCLUSIONS}

Based on the summary of major findings of the study, the following conclusions are drawn:

1. The findings have established that payment of dividend by petroleum marketing firms in Nigeria positively influence share prices. It is clear that stable and high dividend payment enhance the market value of the shares. The increase in dividend has a signalling effect and reduces information asymmetry. Dividend payout is vital for the petroleum marketing firms to survive in Nigeria.

2. The study has provided both empirical and statistical evidence on the usefulness of preceding year dividend in explaining and predicting the dividend payment of the firms.

3. The study established the absence of optimal dividend policy in the Nigerian petroleum marketing firms given that each firm in the sample pursues a dividend policy that is suitable to it. Firms apply consistent and identifiable patterns of dividend payment appropriate and suitable to it.

4. Finally, the study is in support of arguments that dividend policy is relevant and confirmed the work of Lintner (1956) and Gordon (1962). It rejected the position of Miller sand Modigliani (1961) as their assumptions do not fit to the Nigerian environment. The evidences in this study are consistent with the work of Mainoma (2001), Nishat and Irfan (2003) and Musa (2005).

\section{RECOMMENDATIONS}

As a response to the balanced evidence of this study the following recommendations are hereby suggested:

1. Managements of petroleum marketing firms need to identify the shareholder's interest in setting dividend policy that would balances their need for current income and retention for recapitalization to maximize value of the firms. With current deregulation program, private sector participation in businesses has increased, thereby increasing the need for dividend payout as a return to various investors.

2. Management need to employ other alternative methods of declaring dividend to have enough retained earnings. Stock split and bonus issue tend to encourage investors by virtue of its psychological impact.

3. Government need to intervene in the economy by taking effective measures in order to boost private sector participation. Measures such as control of inflation, enactment and enforcement of 
laws to ensure shareholders protection are desirable. High inflation rate can bring about fear of lost in value of investment if capital appreciation does not commensurate with rising prices and willingness to invest in shares can decrease if shareholder's right is not protected.

4. There is need for Nigerian firms not only those engaged in marketing petroleum product to imbibe the habit of stable dividend policy against the fluctuating pattern by virtue of its information content. Increase in earnings need to be maintained and should follow a sustainable increase in dividend for a relatively long period. Stable dividend announcement conveys information that will provide the needed influence on the market value of the firm.

\section{REFERENCES}

1. Adefila, J. J., Oladipo, J. A., \& Adoeti, J. O. (2000). The Effect of Dividend Policy on the Market Price of Shares in Nigeria: Case Study of Fifteen Quoted Companies. Journal of Accounting and Finance, 2(4), 1-10.

2. Aggarwal, R., Cao, J., \& Chen, F. (2012). Information Environment, Dividend Changes, and Signaling: Evidence from ADR Firms. Contemporary Accounting Research, 29(2), 403-431.

3. Ahmed, S., \& Murtaza, H. (2015). Critical Analysis of the Factors Affecting the Dividend Payout: Evidence from Pakistan. International Journal of Economics, Finance and Management Sciences, 3(3), 204-212.

4. Al-ghazali, A. M. (2014). The Economic and Behavioural Factors Affecting Corporate Dividend Policy: Theory and Evidence. Ph.D. Thesis. University of Bath, Claverton Down, United Kingdom.

5. Al-Kuwari, D. (2009). Determinants of the dividend policy in emerging stock exchanges: The case of GCC countries. Global Economy \& Finance Journal, 2(2), 38-63.

6. Al-Malkawi, H.-A. N. (2007). Determinants of Corporate Dividend Policy in Jordan: An Application of the Tobit Model. Journal of Economic \& Administrative Sciences, 23(2), 44-70.

7. Al-Malkawi, H. N., Rafferty, M., \& Pillai, R. (2010). Dividend Policy: A Review of Theories and Empirical Evidence. International Bulletin of Business Administration, 9(9), 171-200.

8. Al-Twaijry, A. A. (2007). Dividend Policy and Payout Ratio: Evidence from the Kuala Lumpur Stock Exchange. The Journal of Risk Finance, 8(4), 349-363.

9. Arko, A. C., Abor, J., Adjasi, C. K. D., \& Amidu, M. (2014). What influence dividend decisions of firms in Sub-Saharan African? Journal of Accounting in Emerging Economies, 4(1), 57-78.

10. Baker, H. K., \& Imad, J. (2017). How Moroccan Institutional Investors View Dividend Policy. Managerial Finance, 45(2), 227-241.

11. Baker, H. K., \& Kapoor, S. (2015). Dividend policy in India: New survey evidence. Managerial Finance, 41(2), 182-204.

12. Baker, H. K., Kilincarslan, E., \& Arsal, A. H. (2018). Dividend policy in Turkey: Survey evidence from Borsa Istanbul firms. Global Finance Journal, 35, 43-57.

13. Baker, H. K., \& Powell, G. E. (2000). Determinants of Corporate Dividend Policy: A Survey of NYSE Firms. Financial Practice \& Education, 10(1), 29-41.

14. Baker, H. K., \& Powell, G. E. (2012). Dividend policy in Indonesia: Survey evidence from executives. Journal of Asia Business Studies, 6(1), 79-92.

15. Baker, H. K., Veit, E. T., \& Powell, G. E. (2001). Factors Influencing Dividend Policy Decisions of NASDAQ Firms. The Financial Review, 36(3), 19-37.

16. Baker, M., \& Wurgler, J. (2004). A catering theory of dividends. Journal of Finance, 59(3), 1125-1165.

17. Bhattacharya, S. (1979). Imperfect Information, Dividend Policy, and "The Bird in the Hand" Fallacy. The Bell Journal of Economics, 10(1), 259-270.

18. Bishop, S. R., Harvey, R. C., Robert, W. F., \& Garry, J. T. (2000). Corporate Finance. Prentice Hall Inc., Sydney.

19. Bradford, W., Chen, C., \& Zhu, S. (2013). Cash dividend policy, corporate pyramids, and ownership structure: Evidence from China. International Review of Economics and Finance, 27, 445-464.

20. Bulan, L. T., \& Narayanan, S. (2009). The Firm Life Cycle Theory of Dividends. In Dividends and Dividend Policy (pp. 201-213).

21. Celsing, W. (2017). Share Price Reaction to Dividend Announcements. MSc Thesis. Lund University.

22. Chekole, D. Y. (2016). Internal Determinants of Dividend Payout in Private Commercial Banks in Ethiopia. MSc Thesis. Addis Ababa University.

23. Chelimo, J. K., \& Kiprop, S. K. (2017). Effect of Dividend Policy on Share Price Performance: A Case of Listed Insurance Companies at the Nairobi Securities Exchange, Kenya. International Journal of Accounting, Finance and Risk Management, 2(3), 98-106.

24. Deangelo, H., \& Deangelo, L. (2006). Dividend policy and the earned / contributed capital mix : a test of the life-cycle theory, 81, 227-254.

25. Denis, D. J., \& Osobov, I. (2008). Why do firms pay dividends? International evidence on the determinants of dividend policy. Journal of Financial Economics, 89(1), 62-82.

26. Dhaliwal, D. S., Merle, E., \& Robert, T. (1999). A Test of the Theory of Tax Clienteles for Dividend Policies. National Tax Journal, 52, 179-194

27. Easterbrook, F. H. (1984). Two Agency-Cost Explanations of Dividends. The American Economic Review, 74(4), 650-659.

28. Edwin, J. E., \& Martin, J. G. (1970). Marginal Stockholder Tax Rates and the Clientele Effect. The Review of Economics and Statistics, 52(1), 68-74.

29. Fairchild, R., Guney, Y., \& Thanatawee, Y. (2014). Corporate dividend policy in Thailand: Theory and evidence. International Review of Financial Analysis, 31, 129-151.

30. Fama, E. F., \& French, K. R. (2001). Disappearing dividends: Changing firm characteristics or lower propensity to pay? Journal of Financial Economics, 60(1), 3-43.

31. Fama, E. F., \& Jensen, M. C. (1983). Separation of Ownership and Control. Journal of Law and Economics, 26(2), 301-325.

32. Ferris, S. P., Jayaraman, N., \& Sabherwal, S. (2009). Catering effects in corporate dividend policy: The international evidence. Journal of Banking \& Finance, 33(9), 1730-1738.

33. Firth, M., Gao, J., Shen, J., \& Zhang, Y. (2016). Institutional stock ownership and firms' cash dividend policies: Evidence from China. Journal of Banking and Finance, 65, 91-107.

34. Gonzalez, M., Molina, C. A., Pablo, E., \& Rosso, J. W. (2017). The effect of ownership concentration and composition on dividends: Evidence from Latin America. Emerging Markets Review, 30, 1-18.

35. Gordon, M. J. (1963). Optimal Investment and Financing Policy. The Journal of Finance, 18(2), 264-272.

36. He, W. (2012). Agency Problems, Product Market Competition and Dividend Policies in Japan. Journal of Accounting \& Finance, 52, 873-901.

37. Hendra, W., Tandelilin, E., Mudjilah, R., \& Hermeindito. (2016) Intellectual Capital and Agency Conflict. Indian Journal of Finance, 10(12), 39-55

38. Jabbouri, I. (2016). Determinants of corporate dividend policy in emerging markets: Evidence from MENA stock markets. Research in International Business and Finance, 37, 283-298.

39. Jensen, M. C. (1986). Agency Costs of Free Cash Flow, Corporate Finance, and Takeovers. The American Economic Review, 76(2), $323-329$.

40. Jensen, M. C., \& Meckling, W. H. (1976). Theory of the firm: Managerial behavior, agency costs and ownership structure. Journal of Financial Economics, 3(4), 305-360.

41. Khan, H. (2015). A Comprehensive Examination on the Decomposition of the Dividend Puzzle in the Malaysian Stock Market. Ph.D. Thesis. Universiti Teknologi Malaysia.

42. Koussis, N., Martzoukos, S. H., \& Trigeorgis, L. (2017). Corporate liquidity and dividend policy under uncertainty. Journal of Banking and Finance, 75, 200-214.

43. Kuo, J. M., Philip, D., \& Zhang, Q. (2013). What drives the disappearing dividends phenomenon? Journal of Banking and Finance, 37(9), 3499-3514.

44. Lang, L. H. P., \& Litzenberger, R. H. (1989). Dividend announcements. Cash flow signalling vs. free cash flow hypothesis? Journal of Financial Economics, 24(1), 181-191.

45. Livoreka, B., Hetemi, A., Shala, A., Hoti, A., \& Asllanaj, R. (2014) Theories on Dividend Policy: Empirical Research in Joint Stock Companies in Kosovo. Procedia Economics and Finance, 14(14), 387-396.

46. Masum, A. A. (2014). Dividend Policy and Its Impact on Stock Price: A Study on Commercial Banks Listed in Dhaka Stock Exchange. Global Disclosure of Economics and Business, 3(1), 9-20.

47. Michelle, R. C., Martin, S. F., \& George, H. T. (2012). Corporate Finance: A Practical Approach. (2nd Editio). Hoboken, USA: John Wiley \& Sons. 
48. Miller, M. H., \& Modigliani, F. (1961). Dividend Policy, Growth, and the Valuation of Shares. The Journal of Business, 34(4), 411-433.

49. Miller, M., \& Rock, K. (1985). Dividend Policy under Asymmetric Information. The Journal of Finance, 40(4), 1031-1051.

50. Mukhtar, M. B. (2015). Ownership Structure and Dividend Policy: An Analysis of Consumer Goods Industry In Nigeria. In 17th International Academic Conference, Vienna (pp. 25-38).

51. Olang, M. A., Akenga, G. M., \& Mwangi, J. K. (2015). Effect of Liquidity on the Dividend Payout by Firms Listed at the Nairobi Securities Exchange. Science Journal of Business and Management, 3(5), 196-208.

52. Oliver, C. E., Iniviei, S. E., \& Edori, S. D. (2016). Effect of Dividend Policy on the Value of Firms (Emperical Study of Quoted Firms in Nigeria Stock Exchange). Research Journal of Finance and Accounting, 7(3), 17-24.

53. Oyedeko, Y. O., \& Adeneye, Y. B. (2017). Determinants of Dividend Policy: Controlling for Political Stability in Pre-crisis, Crisis and Post-Crisis Periods. American Journal of Business, Economics and Management, 5(5), 58-67.

54. Pandey, N. S., \& Ashvini, N. (2016). A Study on Determinants of Dividend Policy: Empirical Evidence from FMCG Sector in India. Pacific Business Review International, 1(1), 135-141.

55. Rozeff, M. S. (1982). Growth, Beta and Agency Costs as Determinants of Divided Payout Ratios. Journal of Financial Research, V(3), 249-259.

56. Sa'adu, A. H., \& Abdu, J. B. (2016). Mediating Effect of Liquidity on Firm Performance and Dividend Payout of Listed Manufacturing Companies in Nigeria. Journal of Economic Development, Management, IT, Finance and Marketing, 8(March), 15-35.

57. Shao, L., Kwok, C. C. Y., \& Guedhami, O. (2013). Dividend Policy: Balancing Shareholders'and Creditors'Interests. Journal of Financial Research, XXXVI(1), 43-66.

58. Stulz, R. M. (2000). Merton Miller and Modern Finance. Financial Management, 29(4), 119-131.

59. Tadele, T. (2017). Determinants of dividend policy In Ethiopian private banks. MSc Thesis. Addis Ababa University.

60. Teresiah, C. (2014). The Relationship between Dividend Payout and Financial Performance: A study of Listed Companies in Kenya. MSc Thesis. University of Nairobi.

61. Tse, C.-B. (2005). Use Dividends to Signal or Not: An Examination of the UK Dividend Payout Patterns. Managerial Finance, 31(4), 12-33.

62. Van Horne, J. C., \& Wachowicz, J. M. J. (2005). Instructor's Manual Fundamentals of Financial Management (20th Editi). England: Pearson Education Limited.

63. Walter, J. E. (1967). Corporate Dividend Policy. Journal of Business, 40(4), 550-551.

64. Zakaria, Z., Muhammad, J., \& Zulkifli, A. H. (2012). The Impact of Dividend Policy on the Share Price Volatility: Malaysian Construction and Material Companies. International Journal of Economics and Management Sciences, 2(5), 1-8.

\section{AUTHORS PROFILE}

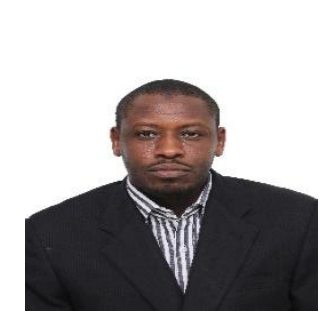

1. Alhaji Ali Tijjani, born on $20^{\text {th }}$ august, 1980, in Goniri, Gujba Local Govt in Yobe state, Nigeria, married with children, I did my $\mathrm{BSc}$ in Accounting, University of Maiduguri, and MSc in Bayero University Kano all in Nigeria. I am a lecturer in Accountancy department, faculty of social and management sciences, Yobe state university. Currently undergoing $\mathrm{PhD}$ program in the faculty of management, Universiti Teknologi, Malaysia. My research field is Finance.

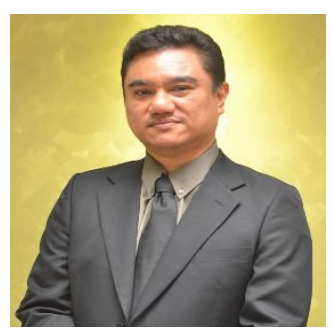

2.Dr. Mohd Norfian Alifiah obtained his $\mathrm{PhD}$ in Business Management, with specialization in Finance from Universiti Teknologi Mara (UiTM), Malaysia. He is an Associate Member of Malaysian Institute of Accountants (MIA), Malaysian Institute of Management (MIM) and Malaysian Finance Association (MFA). His area of research interest is bankruptcy, financial distress, capital structure and working capital management. He had managed to guide two $\mathrm{PhD}$ candidates towards graduation and he currently has five $\mathrm{PhD}$ candidates doing their $\mathrm{PhD}$ under his supervision in the area of accounting and finance. He is also involved with some research grants such as Research University Grants and Fundamental Research Grants Scheme. He had published some articles in international journals that can be found online in the internet

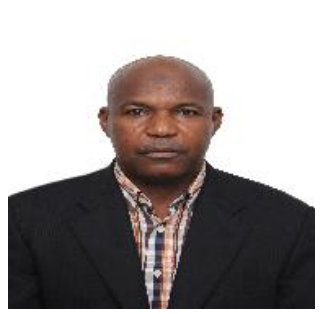

3.Gana Kafiya Wakil was born and raised in a small countryside village of Kafiya in North-Ease Nigeria in 1963 , married with children. I obtained BSc Accountancy from University of Maiduguri, MSc Accounting and Finance from Adamawa State University and MBA (Finance) at University of Maiduguri all in Nigeria. I also worked as a lecturer with the Federal Polytechnic Damaturu. A member of Association National Accountants of Nigeria and currently $\mathrm{PhD}$ student at the Universiti Teknologi Malaysia. Area of research is auditing, accounting and finance 